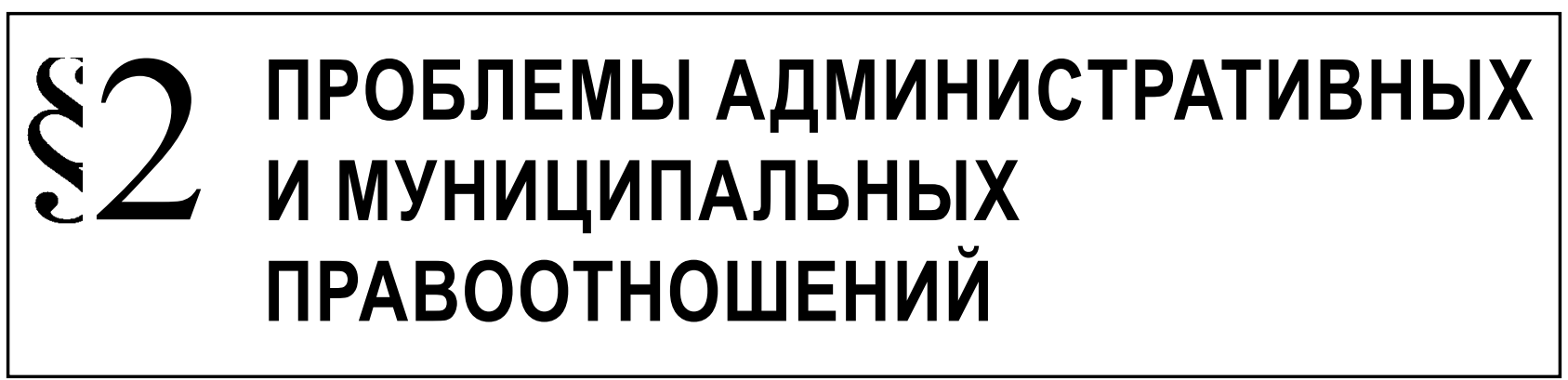

Адарченко Е.О.

\title{
ЮРИДИЧЕСКОЕ ЛИЦО ПУБЛИЧНОГО ПРАВА КАК ЭЛЕМЕНТ ДЕЦЕНТРАЛИЗАЦИИ ПУБЛИЧНОГО УПРАВЛЕНИЯ
}

\begin{abstract}
Аннотация: Предметом исследования статьи являются общественные отношения складывающиеся при осуществлении публичного (государственного) управления. Рассматриваются различные теории определения публичного управления а также субъекты его осуществляемые. Анализируются функции, цели, задачи публичного (государственного) управления.При решении субъектного состава осуществления публичного управления упор делается на включение в него признаваемых нами юридических лиц публичного права, как формирований, наделенных государственно-властными полномочиями. Юридические лица публичного права в статье рассматриваются в качестве субъекта, осуществляемого государственное администрирование, $в$ частности реализации административных полномочий и функций. Статья использует сравнительно-правовой метод исследования, путем сопоставления различных звеньев в цепочке осуществления государственного управления; а также путем сравнения различных авторских теорий публичного управления. Статья рассматривает конструкцию юридического лица публичного права в качестве субъекта, участвующего в осуществлении публичного (государственного) управления. Наделяя юридические лица публичного права определенными функциями и задачами публично-властного характера, государство таким образом децентрализирует собственные правомочия нижестоящим формированиям (органам исполнительной власти, Центральному Банку, государственным корпорациям). Поэтому мы предлагаем признать юридические лица публичного права звеном перераспределения власти и публичных полномочий.

Ключевые слова: государство, управление, публичное юридическое лицо, администрирование, децентрализаиия, субъекты, исполнительная власть, полномочия, обязанности, перераспределение.

Review: The subject of the research includes social relations appearing in the result of public (state) management. The article considers various theories of public management definition and its subjects. The author analyzes the functions, aims and goals of public management. When defining the subject matter of public management execution the author emphasizes the inclusion of recognized legal entities of public law as the state authorized entities. Legal entities of public law are considered in the article as subjects executing state administration, particularly exercising administrative authorities and functions. The author uses the comparative-legal metod by means of comparison of different stages in the succession of public management execution; and by means of comparison of different theories of public management. The article considers the construction of a legal entity of public law as a subject participating in the execution of public management. Authorizing legal entities of public law with particular functions and goals of public-authoritative character the state yields its own competences to subordinate branches (executive bodies, the Central Bank, state corporations). Therefore the author suggests the recognition of legal entities of public law as parts of public authority and competences redistribution.

Keywords: state, management, public legal entity, administration, decentralization, subjects, executive authority, competences, responsibilities, redistribution.
\end{abstract}

$\prod$ олноценное развитие государства в целом, как сложноорганизованного формирования, защищающего и представляющего права и интересы своего населения во многом зависит от разумного, эффективного и целенаправленного публичного управления. Рассмотрение механизма публичного управления предполагает выделение различных элементов, составляющих данное 
управление. Первоначально необходимо отметить, что публичное управление-это многоуровневое осуществление государственных функций и задач различными субъектами публичной власти. К указанным субъектам публичной власти мы считаем оправданным, следует относить и существующие юридические лица публичного права.

Справедливую характеристику государственного управления, на наш взгляд, дает проф. Понкин И.В., который представляет государственное управление как вид государственно-властной деятельности в целях достижения, реализации, охраны и защиты публичных интересов, обеспечения регулятивных функций государства и ведения делами государства, содержанием которой является комплексное планирование, правовое обеспечение и осуществление законодательных, исполнительно-административных, судебных и контрольнонадзорных полномочий органов государственной власти, включая правовое и организационно-ресурсное обеспечение, администрирование и реализацию последовательностей и комплексов управленческих решений и установленных законом инструментов государственно-регулируещего и государственно-администрирующего воздействия в отношении различных сегментов предметнообъектной области такого управления, осуществление контрольно-надзорной и иной правоохранительной деятельности в указанной области ${ }^{1}$. При анализе указанного авторского определения государственного управления следует обратить внимание на достаточно ярко и отчетливо продемонстрированные функции и цели публичного управления, а также виды публичной деятельности осуществляемые в рамках данного управления. Характерной чертой публичного управления следует считать возможность обеспечения функционирования как различных ветвей государственной власти так и некоторые виды негосударственных организаций. В указанном аспекте нас интересует исключительно исполнительная ветвь власти и негосударственные организации, которые наделены одним из элементов публичного управленияадминистративной деятельностью.

Отличное видение государственного управления у А.С.Сухарева, который считает, что это вид государственного администрирования, осуществляемый

1 См.: Понкин И.В. Теория государственного управления: инструменты государственного управления и государственной политики //Административное право и процесс.-2014.№1.-C.28. уполномоченным лицом в рамках структуры государственного органа в отношении лиц, находящихся с ним в состоянии организационной подчиненности в целях обеспечения надлежащего функционирования структуры государственного органа и организационно подчиненных ему лиц ${ }^{2}$. С данным определением мы не согласны по нескольким позициям.Во-первых, автор отождествляет возможность осуществления государственного управления исключительно с государственными органами. Мы же считаем, что процесс государственного управления пронизывает собой все формирования наделенные административно-властными полномочиями(юридические лица публичного права).Во-вторых, по мнению автора цель указанного управления это обеспечение должного функционирования именно конкретного государственного органы. По нашему мнению целью государственного (публичного) управления следует признавать обеспечение осуществления государственных функций и задач, направленных на общественно-полезный результат.

Некоторые авторы рассматривают административную деятельность на одном уровне с государственным управлением ${ }^{3}$. Однако нам представляется рассматривать государственное управление и административную деятельность как целое и часть соответственно.

Применительно к юридическим лицам публичного права, которыми в настоящее время следует считать само государство в целом, органы публичной власти, Центральный Банк РФ, существующие государственные корпорации ${ }^{4}$ и публично-правовые компании;следует обозначить их немаловажную роль в осуществлении государственного управления. Если применительно к органам исполнительной власти в вопросе их участия в осуществлении публичного управления не возникает разногласий, то применительно к государственным корпорациям, публично-правовым компаниям и Банку России становится спорным вопрос их ком-

\footnotetext{
2 См.: Сухарев А.С. Административно-правовые средства и методы противодействия коррупции в сфере государственного администрирования // Административное право и процесс.-2014.-№1.-С.51.

3 См.напр.: Государственное управление в России и зарубежных странах: административно-правовые аспекты: монография / Л.Л.Попов, Е.В.Мигачева, С.В.Тихомиров; под ред. Л.Л.Попова. М.: Норма: Инфра-М, 2012.

4 Адарченко Е.О. Государственные корпорации как вид юридических лиц публичного права // Административное и муниципальное право. - 2012. - 7. - С. 13 - 16.
} 
петентной деятельности в рамках осуществления публичного управления. Однако, как мы уже упоминали в предыдущих статьях, компетенция юридических лиц публичного права ${ }^{5}$ как раз и представляет собой реализацию публичных функций и задач, а следовательно в ее рамках и происходит некоторое осуществление публичного управления.

Мы предлагаем рассматривать конструкцию юридического лица публичного права как элемент децентрализации публичного управления. Признавая децентрализацию в качестве процесса перераспределения власти и полномочий между центральными и местными органами государственного управления, а также органами самоуправления с целью повышения эффективности управления различными сферами экономической и социальной жизни общества ${ }^{6}$; мы считаем целесообразным включения в процесс децентрализации юридические лица публичного права, деятельность которых направлена на достижение публичных и целей и задач и которым государство передает некоторые из своих собственных функций.

В рамках концепции проф. Понкина И.В. о децентрализации публичного управления как принципа организации и функционирования публичной власти, различные виды юридических лиц публичного права можно отнести к различным видам децентрализации; например по вертикали децентрализация управления представляется как передача компетенции юридического лица публичного права с федерального уровня на региональный (в данном случае рассматриваются органы исполнительной власти как юридические лица публичного права). Также в рамках данной концепции находят свое место и такие юридические лица публичного права как государственные корпорации и публичные компании: «делегирование отдельных публично-властных и сопряженных с ними полномочий автономным и квазиавтономным государственным организациям, а также государственно-общественным и автономным организациям частного сектора» .

\footnotetext{
Адарченко Е.О Административная правосубъектность юридических лиц публичного права // Административное и муниципальное право. - 2013. - 5. - С. 410 - 414.

6 См.: Энциклопедия государственного управления в России: в 4т. / под общ.ред. В.К.Егорова, отв.ред. И.Н.Барциц: Изд-во РАГС, 2004. С.295.

7 См.: Понкин И.В. Теория государственного управления: децентрализация публичной администрации // Административное право и процесс. 2014. №2. С.30.
}

Децентрализацию публичного управления юридическим лицам публичного права можно рассматривать и как положительный и как отрицательный момент построения демократического государства. С одной стороны, передавая юридическим лицам публичного права различные функции государственного управления, государство стремится преодолеть различные бюрократические барьеры. Однако с другой стороны, по словам Л.В. Кариньо ${ }^{8}$, власть передается должностным лицам, которые больше заботятся об удовлетворении собственных интересов, чем об обеспечении всеобщего благосостояния, и в таком случае децентрализация способствует развитию коррупционной обстановки. Указанную картину можно проследить в рамках деятельности государственных корпораций, руководители которых по-большому счету являются чиновниками и зачастую преследуют собственные интересы, а механизм должной подотчетности госкорпораций не разработан. Поэтому децентрализация может рассматриваться как положительный элемент осуществления государственного управления только в том случае если будет разработан механизм контроля за выполнением переданных компетенций.

На основании того, что под юридическими лицами публичного права мы признаем все формирования обладающие властными полномочиями( государство, субъекты федерации, органы государственной власти различных уровней, государственные корпорации, публично-правовые компании и др.) и чья деятельность направлена на достижение общегосударственных задач; мы считаем необходимым признать осуществление государственного управления как основу деятельности всех юридических лиц публичного права.

\footnotetext{
8 Carino L.V.Decentralization in Southest Asia // Encyclopedia of public administration and public policy / Ed.by E.M.Berman, J.Rabin. Boca Raton: Taylor\&Francis Group, 2008. P.507.
} 


\section{Библиография:}

1. Понкин И.В.Теория государственного управления:инструменты государственного управления и государственной политики//Административное право и процесс.2014.№1.С.28.

2. Сухарев А.С.Административно-правовые средства и методы противодействия коррупции в сфере государственного администрирования//Административное право и процесс.2014.№1.С.51.

3. Государственное управление в России и зарубежных странах:административно-правовые аспекты:монография/ Л.Л.Попов,Е.В.Мигачева,С.В.Тихомиров;под ред.Л.Л.Попова.М.:Норма:Инфра-М,2012.

4. Энциклопедия государственного управления в России:в 4т./под общ.ред. В.К.Егорова,отв.ред. И.Н.Барциц: Издво РАГС,2004.С.295.

5. Понкин И.В.Теория государственного управления: децентрализация публичной администрации//Административное право и процесс.2014.№2.C.30.

6. Carino L.V.Decentralization in Southest Asia//Encyclopedia of public administration and public policy/Ed.by E.M.Berman,J. Rabin. Boca Raton: Taylor\&Francis Group,2008.P.507.

7. Адарченко Е.О Административная правосубъектность юридических лиц публичного права // Административное и муниципальное право. - 2013. - 5. - C. 410 - 414. DOI: 10.7256/1999-2807.2013.05.3.

8. Адарченко Е.О. Государственные корпорации как вид юридических лиц публичного права // Административное и муниципальное право. - 2012. - 7. - С. 13 - 16.

\section{References (transliterated):}

1. Ponkin I.V.Teoriya gosudarstvennogo upravleniya:instrumenty gosudarstvennogo upravleniya i gosudarstvennoi politiki//Administrativnoe pravo i protsess.2014.№1.S.28.

2. Sukharev A.S.Administrativno-pravovye sredstva i metody protivodeistviya korruptsii $\mathrm{v}$ sfere gosudarstvennogo administrirovaniya//Administrativnoe pravo i protsess.2014.№1.S.51.

3. Gosudarstvennoe upravlenie v Rossii i zarubezhnykh stranakh:administrativno-pravovye aspekty:monografiya/ L.L.Pop ov,E.V.Migacheva,S.V.Tikhomirov;pod red.L.L.Popova.M.:Norma:Infra-M,2012.

4. Entsiklopediya gosudarstvennogo upravleniya v Rossii:v 4t./pod obshch.red. V.K.Egorova,otv.red. I.N.Bartsits: Izd-vo RAGS,2004.S.295.

5. Ponkin I.V.Teoriya gosudarstvennogo upravleniya: detsentralizatsiya publichnoi administratsii//Administrativnoe pravo i protsess.2014.№2.S.30.

6. Carino L.V.Decentralization in SouthestAsia//Encyclopedia of public administration and public policy/Ed.by E.M.Berman,J. Rabin. Boca Raton: Taylor\&Francis Group,2008.P.507.

7. Adarchenko E.0 Administrativnaya pravosub"ektnost' yuridicheskikh lits publichnogo prava // Administrativnoe i munitsipal'noe pravo. - 2013. - 5. - C. 410 - 414. DOI: 10.7256/1999-2807.2013.05.3.

8. Adarchenko E.O. Gosudarstvennye korporatsii kak vid yuridicheskikh lits publichnogo prava // Administrativnoe i munitsipal'noe pravo. - 2012. - 7. - C. 13 - 16. 